\title{
Dietary patterns of obese children: Maternal perceptions and experiences
}

\section{Práticas alimentares de crianças com obesidade: percepções e vivências maternas}

Marina Linhares Bezerra CAMPOS

Márcia Maria Tavares MACHADO²

Daniela Vasconcelos de AZEVEDO3

Kellyanne Abreu SILVA ${ }^{4}$

A B S T R A C T

\section{Objective}

To understand maternal perceptions and experiences regarding the eating habits of obese children aged five to nine years.

\section{Methods}

This is a qualitative research, and semi-structured interviews and discourse analysis were used to interpret narratives of 13 women from the city of Fortaleza, Ceará state, Brazil.

\section{Results}

These women described the eating habits of their obese children in terms of how they eat and mentioned: eating fast, eating in front of the television, secret eating, eating large amounts of food, and the consumption of processed foods that are high in fat, sugars, and sodium.

\section{Conclusion}

Seeing the mother and her obese child as a unit that needs support and guidance is a big step to plant the seeds to reap the rewards, i.e., exerting important impacts on the lives of these families and on the current scenario of childhood obesity.

Keywords: Feeding. Qualitative analysis. Pediatric obesity.

1 Consultório particular. Fortaleza, CE, Brasil.

2 Universidade Federal do Ceará, Faculdade de Medicina, Departamento de Saúde Coletiva. Av. da Universidade, 2932, Benfica, 60020-180, Fortaleza, CE, Brasil. E-mail:<marciamachadoufc@gmail.com>

3 Universidade Estadual do Ceará, Centro de Ciências da Saúde, Programa de Pós-Graduação em Nutrição e Saúde. Fortaleza, CE, Brasil.

${ }^{4}$ Universidade Federal do Ceará, Faculdade de Medicina, Departamento de Saúde Coletiva. Fortaleza, CE, Brasil. 


\section{R E S U M O}

\section{Objetivo}

Compreender percepções e vivências maternas acerca das práticas alimentares de crianças com obesidade na faixa etária de cinco a nove anos.

\section{Métodos}

Foi utilizada a abordagem qualitativa, a técnica da entrevista semiestruturada e a análise de discurso para as falas de 13 mulheres da cidade de Fortaleza, Ceará.

\section{Resultados}

A pesquisa revela que as práticas alimentares das crianças com obesidade sob a óptica materna são descritas através da forma como a criança consome os alimentos, dos atos de comer rápido, em frente à televisão, escondido e em grande quantidade, além do consumo de alimentos processados ricos em gordura, açúcares e sódio.

\section{Conclusão}

Enxergar a criança obesa e sua mãe como uma unidade que precisa de uma rede de apoio é um grande passo para plantar sementes e colher frutos com importantes impactos tanto na vida dessas famílias quanto no cenário atual da obesidade infantil.

Palavras-chave: Alimentação. Análise qualitativa. Obesidade pediatric.

\section{INTRODUCTION}

The characteristics of a healthy life are defined during the prenatal period and the first six years of life, and child growth and development are strongly influenced by the family context [1]. Development of healthy eating habits early in life reduces the risk of obesity and its intercurrences in the later life [2].

In Brazil, excess weight and obesity among children aged $\geq 5$ years are common in all income groups and regions of the country. Approximately one-third of boys and girls have been considered to be overweight [3]. This obesity scenario can persist into adulthood since in Brazil as a whole and in the city of Fortaleza (CE), there are, respectively, $51.0 \%$ and $52.8 \%$ of overweight adults and $17.4 \%$ and $18.8 \%$ obese adults [4].

Children eating habits are acquired based on what the mothers learn throughout their life, and the dietary practices are established based on time, health and disease, care, affective, economic, and ritual dimensions of socialization, which communicate with each other building a network. Nutrition and dietary practices are social product, and therefore they cannot be viewed from a disciplinary perspective since the notion of feeding and eating goes beyond the biological dimension [5].

Foods are not chosen only based on how "nutritious" they are, according to the modern nutrition classification, or on their price or just because they are the most frequently advertised. From childhood and onwards, food choices are made based on tactile, gustatory, and olfactory sensations associated with eating, becoming less permeable to the homogenization imposed by the massified food production and distribution [6].

Parents play an important role in the development of children's eating patterns through their behavior, attitudes, and food choices [7,8], which can affect the family environment by making some foods available rather than others and by acting as models of eating behavior [7-10].

It is therefore necessary to have a comprehensive view of dietary patterns, emphasizing the particularities and recurrent human behaviors towards food [11] through an integrative and transdisciplinary perspective of the obese children and their mothers. Approaches used to assess dietary changes should build bridges between quantitative and qualitative 
research aiming at contributing to the understanding of the obesity phenomenon, enabling more effective interventions [12].

However, the literature addressing the interaction between parenting styles, feeding practices, and childhood obesity risk is scarce; thus further research and interventions are needed [13]. Therefore, the objective of the present study was to understand maternal perceptions and experiences regarding the eating habits of obese children.

\section{METHODS}

A qualitative research was carried out from December 2014 to February 2015 in the city of Fortaleza (CE), Brazil, with mothers of obese children aged 5 to 9 years. Fortaleza is divided into seven administrative regions called Secretarias Executivas Regionais (SER, Regional Executive Secretariats). In each SER, the nutritional status of school aged children was assessed by the Programa Saúde nas Escolas (PSE, School Health Program), an intersectoral health and education policy targeted to children, adolescents, youths, and adults for promotion of health and integral education based on the integration between schools and the primary health care network [14]. This study was carried out in SER $\mathrm{VI}$ because it had the highest prevalence of childhood obesity among the children evaluated $(n=797)$.

The inclusion criteria were as follows: mothers of children evaluated by the PSE and classified as obese (>+2 Z-score and $\geq+3$ Z-score), confirmed in the field research following the guidelines for the collection and analysis of anthropometric data in health care services [15]; children aged 5-9 not using medication that may cause obesity; obesity not associated with endocrine disorders; absence of genetic disorders that affect weight; and absence of physical disabilities that affects the ability to stand free in an upright position.
Semi-structured interviews were conducted with the mothers who also completed a questionnaire containing questions about socioeconomic status (Table 1), by a researcher who had professional experience in the school feeding field. Mothers were interviewed in their homes without the child to avoid embarrassment and discomfort. The technique used is aimed at consistent collection of data and at establishing a trust relationship between the researcher and the participant, enabling possible discoveries, without losing the focus on the pre-established questions [16]. The interview guiding questions were: Tell me a little about your child's eating behaviors and how do you see you role in taking care of your children's nutrition?

In order to determine sample size $(n=13)$, theoretical saturation of data was used, i.e., researchers reach a point in their analysis of data that sampling more data will not lead to more information related to their research questions [17].

The interviews were recorded and transcribed in their entirety shortly after the home visit, preserving features of respondents' narratives and words spoken. They were categorized and analyzed by the researchers using discourse analysis [18]; an approach that includes a critical proposal through the use of problem-posing in the analysis of pre-established types of reflection. It investigates the social processes created by the discourses and the relationships between knowledge and power embedded in the discourses $[19,20]$. Silence plays an important role in this method of analysis, and it is at the same time ambiguous and eloquent. There are silences that actually 'talk' and there are silenced narratives; neither speech nor silence can speak by themselves; they express relationships and say a lot about the person using them [21].

The present study was approved by the Research Ethics Committee of the Universidade Federal do Ceará (Protocol n 1.000.308, according to the Resolution $n^{\circ} 466 / 12$ of the Conselho Nacional de Saúde [22]). 


\section{RESULTS AND DISCUSSION}

The women participating in this study $(n=13)$ had a mean age of 33 years. They were predominantly housewives $(n=5)$. All of them were literate, with Primary $(n=6)$ and Secondary Education $(n=7)$. Domestic partnership was the most common marital status $(n=8)$ among the women investigated. Household income varied from less than the minimum wage $(n=1)$ to more than three times $(n=1)$ the minimum wage; but most $(n=11)$ earned 1-3 times the minimum wage. Two-thirds of the women $(n=8)$ were beneficiaries of the Programa Bolsa Familia (a Conditional Cash Transfer program) i.e., a situation associated with living in poverty, as summarized in Table 1. The average number of persons per household was
4.9, the number of children per mother was 2.9. Only one of these women had another obese child.

Thematic analysis identified four categories related to maternal perceptions and experiences regarding the eating habits of their children, including: "I think my child eats too much"; "Eating in front of the television"; "Amount of food, intonation and word-stress, and request for help"; and "Food consumption and maternal care".

\section{"I think my child eats too much ..."}

Based on the maternal narratives about their perceptions and experiences regarding the

Table 1. Socioeconomic characterization of mothers of obese children. Fortaleza (CE), Brazil, 2015.

\begin{tabular}{|c|c|c|c|c|c|c|}
\hline Mother & Age & Occupation & Education level & Income & $\begin{array}{l}\text { Beneficiary of the } \\
\text { conditional cash } \\
\text { transfer program }\end{array}$ & Marital status \\
\hline R1 & 33 & Housewife & $\begin{array}{l}\text { Complete Elementary and } \\
\text { Middle School }\end{array}$ & $\begin{array}{l}1-3 \text { times the } \\
\text { minimum wage }\end{array}$ & Yes & $\begin{array}{l}\text { Domestic } \\
\text { partnership }\end{array}$ \\
\hline R2 & 34 & Manicurist & Complete High School & $\begin{array}{l}1-3 \text { times the } \\
\text { minimum wage }\end{array}$ & No & Single \\
\hline R3 & 27 & Housewife & Incomplete High School & $\begin{array}{l}1-3 \text { times the } \\
\text { minimum wage }\end{array}$ & Yes & $\begin{array}{l}\text { Domestic } \\
\text { partnership }\end{array}$ \\
\hline R4 & 23 & Seamstress & Complete High School & $\begin{array}{l}1-3 \text { times the } \\
\text { minimum wage }\end{array}$ & No & Single \\
\hline R5 & 29 & Seamstress & Incomplete High School & $\begin{array}{l}1-3 \text { times the } \\
\text { minimum wage }\end{array}$ & No & $\begin{array}{l}\text { Domestic } \\
\text { partnership }\end{array}$ \\
\hline R6 & 44 & Housewife & Complete High School & $\begin{array}{l}>3 \text { times the } \\
\text { minimum wages }\end{array}$ & No & $\begin{array}{l}\text { Domestic } \\
\text { partnership }\end{array}$ \\
\hline R7 & 26 & Housewife & $\begin{array}{l}\text { Incomplete Elementary and } \\
\text { Middle School }\end{array}$ & $\begin{array}{l}1-3 \text { times the } \\
\text { minimum wage }\end{array}$ & Yes & $\begin{array}{l}\text { Domestic } \\
\text { partnership }\end{array}$ \\
\hline R8 & 39 & Housewife & $\begin{array}{l}\text { Complete Elementary and } \\
\text { Middle School }\end{array}$ & $\begin{array}{l}<1 \text { - less than the } \\
\text { minimum wage }\end{array}$ & Yes & Single \\
\hline R9 & 45 & Small business owner & $\begin{array}{l}\text { Complete Elementary and } \\
\text { Middle School }\end{array}$ & $\begin{array}{l}1-3 \text { times the } \\
\text { minimum wage }\end{array}$ & No & $\begin{array}{l}\text { Domestic } \\
\text { partnership }\end{array}$ \\
\hline R10 & 37 & Maid & $\begin{array}{l}\text { Complete Elementary and } \\
\text { Middle School }\end{array}$ & $\begin{array}{l}1-3 \text { times the } \\
\text { minimum wage }\end{array}$ & Yes & $\begin{array}{l}\text { Domestic } \\
\text { partnership }\end{array}$ \\
\hline R11 & 28 & Store clerk & Complete High School & $\begin{array}{l}1-3 \text { times the } \\
\text { minimum wage }\end{array}$ & Yes & $\begin{array}{l}\text { Domestic } \\
\text { partnership }\end{array}$ \\
\hline R12 & 35 & Small business owner & $\begin{array}{l}\text { Incomplete Elementary and } \\
\text { Middle School }\end{array}$ & $\begin{array}{l}1 \text { to } 3 \text { times the } \\
\text { minimum wage }\end{array}$ & Yes & $\begin{array}{l}\text { Domestic } \\
\text { partnership }\end{array}$ \\
\hline R13 & 31 & Housewife & Complete High School & $\begin{array}{l}1-3 \text { times the } \\
\text { minimum wage }\end{array}$ & Yes & $\begin{array}{l}\text { Domestic } \\
\text { partnership }\end{array}$ \\
\hline
\end{tabular}


eating habits of their obese children, it was possible to identify the way the children consume food, the amount of food consumed, and the consumption of foods high in fats and sugars:

I think he eats too much... Sometimes I feel bad because there's no food left for others (laughter), he always overeats [...] When he starts eating, eating, eating, he doesn't eat normally like everyone else. He fills his mouth so much, it seems like he is terribly hungry, like he wants to eat everything at once [...] (R.4, respondent 4).

In the morning he eats a lot, quite a lot, in the morning is three loaf of bread. He is not satisfied with just one, it has to be three bread; sometimes he eats up to four [...] He eats too quickly [...] he finishes before us [...] I think he doesn't chew (R.7).

The way the mothers experience and perceive their obese children eating habits was emphasized by their comments such as 'eating quickly', 'without chewing', 'in front of the television', and 'eating large amounts of food per meal'. In a case study carried out in the city of Goiânia (GO), Brazil, in 2012 involving 80 children aged 7-9 years attending schools that participated in the PSE, fast chewing was significantly associated with childhood obesity [23]. Increased speed of eating is an important aspect of eating behavior, and it has recently been associated with loss of control of food intake and obesity $[24,25]$.

\section{Eating in front of the television}

Only two out of the 13 women interviewed reported making an effort to have meals around the dining table rather than eating in front of the television; and one of them, R9, mentioned eating meals with her son. The others reported that while their children are having lunch, they engage in other activities. Eating at the family table is a child's eating habit influenced by the maternal behavior of sitting around the table during meals.
He eats at the table here at home; it's always at the table. I don't let him eat anywhere else [...] I eat with him; we always have lunch together [...] (R.9).

[...] We rarely eat lunch together. One eats lunch here, the other eats there. He usually eats lunch while watching TV in his room (R.10).

Not having meals around the dining table increases the chances that the child will eat low-quality foods [26]. Evidence suggests that eating meals with family members is associated with the protection against the development of obesity [27]. A cohort study with 2,117 adolescents, who were racially/ethnically and socioeconomically diverse, showed that eating family meals together five or more times per week was protective against becoming overweight and obese 10 years later or more in young adulthood [28].

Watching television during meals may lead to increased food consumption since television can affect several processes that regulate food intake [29]. Borghese et al. [30] carried out a cross-sectional study of 550 children from Canada in 2013 and found that children who watched more than four hours of the television per day were more likely to develop obesity and consumed more food while watching television than normalweight children.

Parental control over children's eating behaviors brings more benefits for children's nutritional status than parental provision of health education. Thus, the role of parents in the supervision of children's behaviors is essential in order to prevent and control childhood obesity [31].

Dos Passos et al. [32] used a questionnaire to evaluate the subjective parents' perception of eating behaviors of 335 children aged 6-10 years who attended a private school in the city of Pelotas, Rio Grande do Sul, Brazil. The authors found that overweight children had higher scores 
in the following subscales of interest in food food responsiveness, enjoyment of food, emotional eating, and desire to drink - and lower scores in the subscales satiety responsiveness and slowness in eating - when compared to normal weight children.

\section{Amount of food, intonation and word-stress, and request for help}

In the mothers' narratives, it was also observed repetition and stress on particular words when referring to the amount of food their children eat and the way they eat, as if they were trying to call attention and asking for help. Furthermore, there was ambiguity regarding their role in taking care of their children's nutrition. They laughed when they mentioned their children overeating habits and they also reported that, in addition to finishing everything on their plates, their children ate their siblings' food and, in some cases, they ate in secret foods forbidden by their parents or grandparents.

[...] Sometimes I get him eating in secret (R.10).

[...] Sometimes he eats her food (sister) (R.4).

[...] And when he suddenly takes his sister's food, he eats her food [...] He gets a bag (chocolates) and hides among his possessions. He sits at his computer and "tchun, tchun, tchun" (referring to the act of putting chocolates in his mouth) (R.5).

Secret eating was mentioned by a mother as se referred to the way her son found to eat his preferred foods without being reprimanded by his maternal grandmother. Another mother pointed out that her son ate his sister's food because he thought there would not be any food left for him. Such facts reported by the women go beyond the act of eating reaching the biological and social activity, which involves eating practices. The dual and closely related biological and social activity must be taken into account by those who provide guidance about eating practices [11].

Foods and the act of eating are full of meanings. We also eat according to the distribution of the wealth in our society, which is marked by differences, hierarchies, and different ways of eating and eating styles influenced by beliefs and collective imaginaries and representations [6].

Anthropologists highlight the symbolic aspects of food and the many ways food is prepared and eaten in human societies. The acts of seeking, selecting, consuming, and prohibiting some foods are present in all social groups and are guided by different social norms that are full of significations [33]

Eating practices of obese children has many meanings and are perceived by the mothers by the sense of deprivation or restricted access, in which the child eats too much food because they fear not having enough, and prohibition, which can lead to overeating and secret eating.

Therefore, it is up to us, health care professionals, as well to professionals in other fields to try to understand the functioning of families of obese children focusing on the meanings of eating so that we can see beyond and find ways to prevent childhood obesity and provide proper care for obese children.

\section{Food consumption}

Foods usually eaten by the children evaluated at breakfast include bread and butter, porridge, yogurt, coffee, and milk. Most children who go to school only in the afternoon do not eat mid-morning snack because they wake up late and need to get ready for school. Those who go to school in the morning have lunch at school, which includes foods such as rice, beans, meat, noodles, eggs, and soup. A basic school meal consists of rice, noodles, beans, mistura or meat dish (name attributed to animal protein source 
food, such as chicken, fish, beef, and viscera), and a drink such as soft drink, powdered drink mix, or fruit juice. The children did not have the habit of eating vegetables and leafy greens during lunch and dinner. Some children had mid-afternoon snack at school, and those who go to school in the morning had stuffed cookies, bread, fried snacks, and yogurt in the middle of the afternoon. They usually ate lunch food for dinner and do not eat another meal before going to bed.

As for the consumption of foods rich in fats, sugars, and sodium, as reported by the mothers, we identified the consumption of soft drinks, encased meats and cold cuts (sausage, Frankfurter sausage, mortadella, ham etc.), processed juices, packaged snacks, sweets, chocolates, instant noodles, stuffed cookies, milk added with thickening agents and sugar, and fried foods. Two women owned a bodega (small grocery store), which, according to them, stimulates the consumption of industrialized and hypercaloric foods. The children eat these foods every day, but on the weekends, they consume an excessive amount of these foods, as reported by the women:

[...] They eat stuffed cookies, Nescauzinho ${ }^{\circledast}$ (processed chocolate milk box), these are things we have here (in the bodega) [...] It's Xilito, Fandangos ${ }^{\circledR}$ (packaged snacks), I cannot control (R.9).

Here we buy soda, but it's only once a week. There is always a liquid [...] Some days it's powdered mix [...] (R.10).

The dietary pattern associated with obesity and other chronic, noncommunicable diseases is characterized by the excessive consumption of foods high in fats, sugars, and salt and high energy density foods, characteristic of industrialized foods [34]. Consumption of sugary beverages contributes to childhood obesity. Parents need guidance in order to reduce the availability and accessibility of these beverages to limit consumption is important [35].

Fechine et al. [36] carried out a qualitative study in Brazil in a city in the state of Ceará (CE) in 2010 with parents and teachers of public day-care centers, and found that parents perceive industrialized foods as unhealthy, but their use in the household is common. The authors emphasized that there are several factors that can influence the intake of industrialized foods by children and highlighted the need for interventions focusing on schools and families to prevent the indiscriminate use of these type of foods.

The great availability and variety of ultraprocessed products (bread, cookies and crackers, ice cream, chocolate, potato chips, sugarsweetened beverages, processed meats, Frankfurter sausages, canned and preserved foods, etc.) sold at low prices in easily accessible places have led to increased consumption among low-income consumers $[37,38]$.

Removing (replacing) foods that contribute to childhood obesity, increasing physical activity, and engaging families in discussions about health and weight maintenance are important strategies for the prevention and management of childhood obesity [39].

\section{Maternal care}

Maternal care included the choice of foods, food preparation, and amount of food on the plate; it was evidenced by the maternal feelings regarding their concern about their child's diet, emphasizing a paradox between offering both healthy foods and foods high in fat, salt, and sugar, as a way of providing them with nutritious food.

Mothers face real dilemmas because they want to provide their children with healthy food, which would be more expensive. On the other hand, they also want to please their children by offering what they like to eat, sugar and sweets in general. However, their food choices will be actually determined by the material constraints of what they can afford to buy due to their precarious financial situation. High-calorie, 
energy-dense processed foods are cheaper and have greater satiating power, impacting the whole family, when compared to fruits and vegetables, for example [38]. This can be observed in the mothers' narratives:

At the street fair on Saturday, it is cheaper [...] We fill the baskets, but we make sure they have good quality [...] Because there are rotten potatoes, I see them. There is a rotten potato smell. It stinks, right? (R.8).

[...] You have to pay attention how you put foods on the plate to make the child feel like eating (R.2).

In the study by Lindsay et al. [40], childcare providers and parents of preschool children mentioned the importance of planning, buying, and preparing meals in advance. Planning ahead enables serving healthier meals.

According to Rotenberg \& de Vargas [5], dietary habits include food selection, preparation, distribution, and consumption. Mothers start making food choices in food stores, such as supermarkets, bakeries, and street fairs or famer's markets, where they look for fresh food that do not look damaged or smell bad. However, the socioeconomic status of the mothers evaluated in the present study can be considered a barrier to healthier food choices due to their low purchasing power and their low education level. Therefore, health education actions designed for this population should take into account the social setting in which they are inserted since the importance of healthy eating habits must make sense and be feasible so that they can put them into practice.

Sociological analyses of food consumption that address culture and food choices show the contradictions of the commodification of culture, in which there is prevalence of differences in consumption patterns between income, class, and gender groups and stage of life, as well as the non-removal of material constraints and individual idiosyncrasies [6].

Maternal feelings towards the nutritional status of their children were perceived through a change in the tone of voice in their speech. Their tone was softer and gentler and they smiled as they commented on how they took care of their family's food and nutrition, especially their children. This may suggests that they realize having adopted wrong food practices on a daily basis. They have major social difficulties and the lack of financial resources often determines food choices.

Caring for others is a process of a technical nature, but it involves sensitivity interpersonal relationships, and affection display [41]. Family plays an important role as a caregiver, and its performance enables determining behavior patterns in social interactions influencing education and socialization [42].

Using the focus group technique, a qualitative study carried out in Boston (MA), with 44 caregivers and parents of preschool children evaluated the beliefs, attitudes, and dietary practices. The authors found that most of them reported concern with their role of nurturing and educating children aiming to establish healthful nutrition, and they demonstrated the need to compensate for unhealthy practices. Additionally, they encouraged the consumption of new foods by directly involving children with healthy food choices since they can give them a sense of control and openness to new foods [40].

Health promotion programs should be more focused on mothers by emphasizing that an adequate nutritional status can help children in school, by teaching them to prepare healthy foods that their children will encounter in kindergarten, and by providing information on childhood obesity reinforcing what they are doing well and reducing feelings of failure [43].

Effective obesity prevention and therapeutic interventions targeting children and their families are needed to help stop the obesity epidemic [44]. It can be highlighted, in this type of analysis, the importance of providing clear and objective information to mothers and caregivers of obese children about possible behaviors that cause or maintain childhood obesity. The daily dietary 
practices that these women sometimes complained about, according to the way they spoke, or sometimes laughed about and at the same time asked for help, revealing great ambiguity, reinforce the fact that mothers and caregivers of children need guidance on daily practices and on how they should deal with this obesogenic family and social context.

\section{CONCLUSION}

The present study brings us closer to a part of the iceberg called childhood obesity. With the help of Nutrition Anthropology, understanding the perceptions and experiences of the mothers of obese children, elucidates a diagnosis of childhood obesity beyond body weight, risk factors, and list of foods to be consumed. The present study enables us to immerse, although obscurely, in a field called maternal and family singularity, which proved to be the basis for the prevention and treatment of childhood obesity.

The eating habits of obese children were described from the perspective of these women by evidencing how their child consumes food: eating fast, eating in front of the television, secret eating, eating large amounts of food, and the consumption of processed foods that are high in fat, sugars, and sodium. Mother's care was also evidenced by the satisfaction and love they expressed in taking caring of their children's nutrition including the selection and preparation of food. On the other hand, there was ambiguity in the mother's discourse since they complained about their child's eating habits regarding the way they eat, and in other situations they offered foods that were inadequate for daily consumption and the amount of food they mentioned.

Women's silence, crying, and shaky voices clearly showed that many internal problems come to light when it comes to their children nutrition, problems that may never be solved but can be heard and mitigated by effective listening and guidance aiming at understanding the individuals, focusing on their subjectivity.

\section{CONTRIBUTORS}

All authors participated in all phases of the research.

\section{REFER E N C E S}

1. Costa MGFA. Obesidade infantil: práticas alimentares e percepção materna de competências [doutorado]. Portugal: Universidade de Aveiro; 2012.

2. Rosaneli $C F$, Auler Fl, Manfrinato $C B$, Rosaneli $C F$, Sganzerla C, Bonatto $M G$, et al. Avaliação da prevalência e de determinantes nutricionais e sociais do excesso de peso em uma população de escolares: análise transversal em 5.037 crianças. Rev Assoc Med Bras. 2012;58(4):472-6. https://doi.org/ 10.1590/S0104-42302012000400019

3. Instituto Brasileiro de Geografia e Estatística. Pesquisa de orçamentos familiares (2008-2009): antropometria e estado nutricional de crianças, adolescentes e adultos no Brasil. Rio de Janeiro: IBGE; 2010 [acesso: 2010 ago 30]. Disponível em: www.ibge.gov.br/home/estatistica/populacao/ condicaodevida/pof/2008_2009/default.shtm

4. Ministério da Saúde (Brasil). Vigitel Brasil 2013: vigilância de fatores de risco e proteção para doenças crônicas por inquérito telefônico. Brasília: Ministério da Saúde; 2014.

5. Rotenberg $S$, de Vargas S. Práticas alimentares e o cuidado da saúde: as alimentação da criança à alimentação da família. Rev Bras Saúde Matern Infant. 2004;4(1):85-94.

6. Canesqui AM, Garcia RWD. Uma introdução à reflexão sobre a abordagem sociocultural da alimentação. In: Antropologia e nutrição: um diálogo possível. Rio de janeiro: Fiocruz; 2005.

7. Viana V, Candeias L, Rego C, Silva D. Comportamento alimentar em crianças e controlo parental: uma revisão da bibliografia. Aliment Hum. 2009 [acesso 2015 ago 3];15(1):9-16. Disponível em: http://www2.itau.pt/Docs/23.pdf

8. PatrickH, Nicklas T. A review of family and social determinants of children's eating patterns and diet quality. J Am Coll Nutr. 2005;24(2):83-92.

9. Savage J, Fisher J, Birch I. Parental influence on eating behavior: Conception to adolescence. J Law Med Ethics. 2007;35(1):22-34.

10. Brown R, Ogden, J. Children's eating attitudes and behavior: A study of the modeling and control theories of parental influence. Health Educ Res. 2004; 19(3):261-71.

11. Contreras J, Gracia M. Alimentação, sociedade e cultura. 22 ed. Rio de Janeiro: Fiocruz; 2011. 
12. Restrepo MSL. Children's perceptions about of the feeding and nutrition. Percepciones frente a la alimentación y nutrición del escolar. Perspect Nutr Hum. 2007;9(1):23-35.

13. Vollmer RL, Mobley AR. Parenting styles, feeding styles, and their influence on child obesogenic behaviors and body weight: A review. Appetite. 2013;71:232-41.

14. Ministério da Saúde (Brasil). Programa Saúde nas Escolas 2014: passo a passo para adesão. Brasília: Ministério da Educação; 2014 [acesso 2014 maio 21]. Disponível em: http://189.28.128.100/dab/ docs/portaldab/documentos/passo_passo_ adesaoPSE2014.pdf

15. Ministério da Saúde (Brasil). Orientações para a coleta e análise de dados antropométricos em serviços de saúde: Norma Técnica do Sistema de Vigilância Alimentar e Nutricional - Sisvan. Brasília: Ministério da Saúde; 2011 [acesso 2105 jul 21]. Disponível em: http://dab.saude.gov.br/portaldab/biblioteca. php?conteudo=publicacoes/orientacoes_coleta_ analise_dados_antropometricos

16. Souza ER, Minayo MCS, Deslandes SF, Veiga JPC. Construção dos instrumentos qualitativos e quantitativos. In: Minayo MCS, Assis SG, Souza ER, organizadores. Avaliação por triangulação de métodos: abordagem de programas sociais. Rio de Janeiro: Fiocruz; 2005. p.133-56.

17. Fontanella BJB, Ricas J, Turato ER. Amostragem por saturação em pesquisas qualitativas em saúde: contribuições teóricas. Cad Saúde Pública. 2008;24(1):17-27.

18. Duarte R. Entrevistas em pesquisas qualitativas. Curitiba: Educar; 2004. p.213-25.

19. Fairclough N. Analysing discourse: Textual analysis for social research. London: Routledge; 2003 [cited 2015 May 12]. Available from: file:///C:/Users/ usuario/Downloads/ii.\%20Norman_Fairclough_ Analysing_discourse.pdf

20. Orlandi EP. Discurso e leitura. $8^{\mathrm{a}}$ ed. Campinas: Cortez; 2006 [acesso 2015 maio 16]. Disponível em: http://pt.slideshare.net/josebsantos3/enipuccinelli-orlandi-discurso-e-leitura

21. Minayo MCS. O desafio do conhecimento: pesquisa qualitativa em saúde. São Paulo: Hucitec; 2010. p. $143-360$

22. Ministério da Saúde (Brasil). Resolução n 466, de 12 de dezembro de 2012. Aprovar as seguintes diretrizes e normas regulamentadoras de pesquisas envolvendo seres humanos. Diário Oficial da União. Brasília: Conselho Nacional de Saúde; 2012 [acesso 2014 jun 14]. Disponível em: http://bvsms.saude. gov.br/bvs/saudelegis/cns/2013/res0466_12_12_ 2012.html
23. Honório RF, Hardler MCCM. Factors associated with obesity in brazilian children enrolled in the school health program: A case-control study. Nutr Hosp. 2014 [cited 2014 Jul 12];30(3):526-34. Available from: http://www.aulamedica.es/nh/pdf/7095.pdf

24. Berkowitz RI. Identification of an obese eating style in 4-year-old childrenborn at high and low risk for obesity. Obesity. 2010;18(3):505-12.

25. Zandian M, Loakimidis L, Bergström J, Brodin U, Bergh $C$, Leon $M$, et al. Children eat their school lunch too quickly: An exploratory study of the effect on food intake. BMC Public Health. 2012;12:1-20. https://doi.org/10.1186/1471-2458-12-351

26. Molina MdelCB, Lopéz PM, De Faria CP, Cadel NV, Zandonade E. Preditores socioeconômicos da qualidade da alimentação de crianças. Rev Saúde Pública. 2010;44(5):785-32. https://doi.org/ 10.1590/S0034-89102010005000036

27. Hammons AJ, Fiese BH. Is frequency of shared family meals related to the nutritional health of children and adolescents? Pediatrics. 2011;12(6): 1565-74. https://doi.org/10.1542/peds.2010-1440

28. Berge JM, Wall M, Hsueh TF, Fulkerson JA, Larson, $\mathrm{N}$, Neumark-Sztainer $\mathrm{D}$. The protective role of family meals for youth obesity: 10-year longitudinal associations. J Pediatr. 2015;166(2):296-301. https://doi.org/10.1016/j.jpeds.2014.08.030

29. Braude I, Stevenson RJ. Watching television while eating increases energy intake. Examining the mechanisms in female participants. Appetite. 2014;(76):9-16. https://doi.org/10.1016/j.appet. 2014.01.005

30. Borghese MM, Tremblay MS, Leduc G, Boyer C, Bélanger $P$, LeBlanc $A G$, et al. Television viewing and food intake during television viewing innormalweight, overweight and obese 9- to 11-year-old Canadian children: A cross-sectional analysis. J Nutr Sci. 2015;4(e8):1-9. https://doi.org/10.1017/jns. 2014.72

31. Wei DM, Wu LJ, Gao AY, Li Q, Cheng L, Wang HJ. Study on the relations among the screen-based sedentary behaviors, family factors and body mass index of children. Beijing Da Xue Xue Bao. 2015 [cited 2015 Aug 12]; 47(3):390-4. Available from: http://xuebao.bjmu.edu.cn/fileup/PDF/201547 390.pdf

32. Dos Passos DR. Comportamento alimentar infantil: comparação entre crianças sem e com excesso de peso em uma escola do município de Pelotas, RS. Rev Paul Pediatr. 2015;33(1):42-9. https://doi.org/ 10.1016/j.rpped.2014.11.007

33. Daniel JMP, Cravo VZ. Valor social e cultural da alimentação. In: Antropologia e nutrição: um diálogo possível. Rio de janeiro: Fiocruz; 2005. 
34. Souza ADEM, Pereira RA, Yokoo EM, Levy RB, Sichieril R. Alimentos mais consumidos no Brasil: Inquérito Nacional de Alimentação 2008-2009. Rev Saúde Pública. 2013;47(Supl.1):190s-9s. https:// doi.org/10.1590/S0034-89102013000700005

35. Lopez NV, Ayala GX, Corde K, Eisenber CM, Zive MM, Wood C, et al. Parent support and parentmediated behaviors are associated with children'ssugary beverage consumption. J Acad Nutr Diet. 2012;112(4):541-7. https://doi.org/10.1016/j. jand.2011.11.013

36. Fechine ADL, Machado MMT, Lindsay AC, Fechine VAL, Arruda CAM. Percepção de pais e professores sobre a influência dos alimentos industrializados na saúde infantil. Rev Bras Prom Saúde. 2015;28(1):16-22. https://doi.org/10.5020/180 61230.2015.p16

37. Witkowski TH. Food marketing and obesity in developing countries: analysis, ethics, and public policy. J Macromarketing. 2007;27(2):126-37.

38. Monteiro CA, Levy RB, Claro RM, De Castro IRR, Cannon G. Uma nova classificação de alimentos baseada na extensão e propósito do seu processamento. Cad Saúde Pública. 2010;26(11):2039-49. https://doi.org/10.1590/S0102-311X20100 01100005

39. Guerrero AD, Slusser WM, Barreto PM, Rosales NF, Kuo AA. Latina mothers' perceptions of healthcare professional weight assessments of preschool-aged children. Matern Child Health J. 2011;15(8):1308-15.
40. Lindsay AC, Salkeld JA, Greaney ML, Sands FD. Latino family childcare providers' beliefs, attitudes, and practices related to promotion of healthy behaviors among preschool children: A qualitative study. J Obesity. 2015;(ID409742):1-9. https://doi. org/10.1155/2015/409742

41. Waldow VR. Bases e princípios do conhecimento e da arte da enfermagem. Petrópolis: Vozes; 2008.

42. Oliveira, EAR, Da Rocha, SS. O cuidado cultural às crianças na dinâmica familiar: reflexões para a Enfermagem. R Interd. 2015 [acesso 2015 abr 19];8(1):227-33. Disponível em: http://revista interdisciplinar.uninovafapi.edu.br/index.php/ revinter/article/view/302/pdf_198

43. Davis RE, Cole SM, Reyes LI, McKenney-Shubert SJ, Peterson KE. "It hurts a latina when they tell us anything about our children": Implications of Mexican-origin mothers' maternal identities, aspirations, and attitudes about cultural transmission for childhood obesity prevention. Child Obes. 2015;11(5):608-15.

44. Seburg EM, Olson-Bullis BA, Bredeson DM, Hayes MG, Sherwood NE. A Review of primary care-based childhood obesity prevention and treatment interventions. Curr Obes Rep. 2015;4(2):157-73. https://doi.org/10.1007/s13679-015-0160-0

Received: May 20, 2016

Final version: October 26, 2016

Approved: December 5, 2016 


\section{ERRATA}

In article "Dietary patterns of obese children: Maternal perceptions and experiences", with DOI: 10.1590/1678-98652017000200005, published in the Revista de Nutrição, 30(2), 197-207, on page 197:

Where its read:

Kellyanne Silva ABREU, should read Kellyanne Abreu SILVA 